\title{
Study of Microbiological Quality of Fresh Juices Vended in Dhaka City
}

\author{
Kayseri Afroz ${ }^{1}$, Tahmina Shammi ${ }^{1}$, Md. Shahidul Kabir ${ }^{*}$ \\ I, Department of Microbiology, Stamford University Bangladesh
}

\begin{abstract}
Fresh juices sold by the street vendors are rich in nutritional value and considered as popular drink in Dhaka city. They can be easily contaminated by pathogenic bacteria from unhygienic environment of food preparation area and serves as a potential source of food borne outbreaks. Freshly produced juices of papaya $(n=2)$, wood apple $(n$ $=2)$, wood apple and papaya juice $(1)$, lemon $(n=2)$, and sugarcane $(n=3)$ were examined for the total bacterial load, coliforms, Staphylococcus spp., Pseudomonas spp., Vibrio spp., Salmonella spp., and Shigella spp. in this study. Total bacterial load in eight samples were within 0 to $10^{7} \mathrm{cfu} / \mathrm{ml}$, six samples exhibited the presence of staphylococci within the range of 0 to $10^{5} \mathrm{cfu} / \mathrm{ml}$. Total coliforms were detected in six samples which ranged from $10^{4}$ to $10^{5} \mathrm{cfu} /$ ml. Vibrio spp., Salmonella spp., and Shigella spp. were isolated by enrichment and selective plating method. Eight samples demonstrated the presence of Vibrio spp. and none of them were positive for Salmonella spp. and Shigella spp. Antibiotic sensitivity patterns were determined against eight isolates using Erythromycin (15 $\mu$ g), Amoxicillin $(10 \mu \mathrm{g})$, Gentamicin (10 $\mu \mathrm{g})$, Vancomycin (30 $\mu \mathrm{g})$, Ciprofloxacin $(5 \mu \mathrm{g})$, Rifampicin (5 $\mu \mathrm{g})$, Azithromycin $(15 \mu \mathrm{g})$, Neomycin $(10 \mu \mathrm{g})$ and Cefexime $(5 \mu \mathrm{g})$. Klebsiella sp. $(\mathrm{n}=1)$, Vibrio $\mathrm{sp} .(\mathrm{n}=2)$, Enterobacter $\mathrm{sp} .(\mathrm{n}=1)$, and Proteus sp. $(n=1)$ showed multi drug resistance in this study. Contamination of street vended juices pose risks to consumers' health and requires adequate attention of appropriate authority.
\end{abstract}

Key words: Vended juice, Total viable count (TVBC), coliform, drug resistance

Fresh juices sold by street vendors are considered as a popular drink and consumed by millions of people in worm seasons in Bangladesh. Papaya, wood apple, lemon and sugarcane juices are among the most popular juices. These are not only recognized for their nutritive value, minerals and vitamins but also for their sweet taste and aroma ${ }^{1}$. However, microbial contamination of fruits during pre and post harvesting, cleaning, handling and extraction is very common and can be a public health threat to the consumers. There are reports of food borne illness like diarrhea, dysentery, typhoid, cholera etc. associated with the consumption contaminated juice in different areas in Bangladesh and other countries ${ }^{2,3}$.

Fruits commonly carry mold, yeasts and bacteria. Most fruits contain bacterial counts up to $10^{5}-10^{6} \mathrm{cfu} / \mathrm{cm}^{2}$ on their surface ${ }^{4}$ and include pathogens like Escherichia coli O157:H7, species of Salmonella spp., Shigella spp. and Staphylococcus aureus ${ }^{5}$. Some Gram-negative bacteria e.g. Pseudomonas spp., Xanthomonas spp., Enterobacter spp. and Corynebacterium spp. can be found within the fruit pulp and seed as well ${ }^{2}$. Fruits can be contaminated and spoiled in any step from farms to consumer's hand. Use of unhygienic water for dilution, dressing with contaminated ice, improper refrigeration condition, unhygienic environment with swarming houseflies, fruit flies and airborne dust can also act as source of contamination ${ }^{6,7}$. Moreover, mechanically squeezed and often unpasteurized fruit juices can act as ideal media for the growth of many organisms. Another important concern for fresh juice consumption is heavy use of antibiotics for contamination and spoilage prevention. Though recommended not to use last 40 days before harvesting, antibiotics can increase the prevalence of drug resistant organism in fruits and can even cause transmission of resistant gene to consumers and environment ${ }^{4,8}$. Considering the threats posed by the street vended juices, the present study was undertaken to property of isolated bacteria in freshly squeezed juices.

Ten fresh juice samples, papaya juice $(\mathrm{n}=2)$, wood apple juice $(\mathrm{n}=2)$, wood apple and papaya juice $(\mathrm{n}=1)$, lemon juice $(\mathrm{n}=$ $2)$, sugarcane juice $(\mathrm{n}=3)$, were collected from Baily road, Gluisthan, New market, Science Laboratory area between May 2018 and June 2018. After aseptic collection of samples, they were transferred immediately to the laboratory for microbial analysis following standard procedures of American Public Health Association ${ }^{9}$. For microbiological analysis fresh juice samples were homogenized and serially diluted to $10^{-6}$ in normal saline ${ }^{10}$. $0.1 \mathrm{ml}$ of diluted juice samples were introduced and spread plated onto nutrient agar (NA) media for enumerating total viable bacteria (TVB) and Sabouraud Dextrose Agar (SDA) for Total Fungal Count (TFC), respectively ${ }^{11}$. For identification and enumeration of specific pathogenic bacteria $0.1 \mathrm{ml}$ of diluted fresh juice samples were added and spread onto MacConkey Agar (MA), Mannitol Salt Agar (MSA) and Cetrimide Agar (CA) media for selective isolation of Escherichia coli, Staphylococcus spp. and Pseudomonas spp., respectively. SDA plates were incubated at $25^{\circ} \mathrm{C}$ for 48 to 72 hours. The other plates were incubated at $37^{\circ} \mathrm{C}$ for 24 hours. Eschericha coli or Klebsiella spp. were

* Corresponding author:

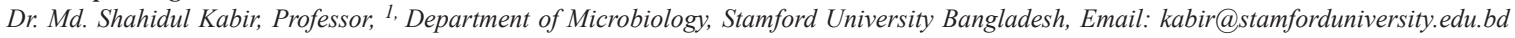


identified by distinguishable pink colony on MacConkey agar followed by biochemical tests. Staphylococcus spp. were identified by characteristic yellow colony on MSA and Pseudomonas spp. by their greenish colony on CA. All media were procured from Himedia limited until mentioned otherwise.

For detection of Salmonella spp. $0.1 \mathrm{ml}$ homogenized sample of fresh juice was inoculated into $9 \mathrm{ml} \mathrm{SCB}$ for enrichment at $37^{\circ} \mathrm{C}$ for 6 hours. For detection of Vibrio spp., $1 \mathrm{ml}$ sample was inoculated into $9 \mathrm{ml}$ Alkaline Peptone Water (APW) by following the same procedure as mentioned before. After enrichment the SCB and APW media containing fresh juice samples were streaked onto Salmonella-Shigella (SS) and Thiosulfate Citrate Bile Salt Sucrose (TCBS) agar, respectively. After that samples were inoculated onto selective agar they were incubated at $37^{\circ} \mathrm{C}$ for 24 hours. Transparent colony with black center on the SS agar indicated the presence of Salmonella spp. and the large, yellow colonies on the TCBS agar is indicative for the presence of Vibrio $\mathrm{spp}^{12}$. Biochemical tests were performed to ensure the identity of the isolates.

Colonies on both selective and differential media were observed carefully. Morphological characteristics of the colonies were studied and cells were visualized by Gram staining. Isolated bacteria were identified by biochemical tests such as, Catalase, Oxidase, Motility, Indole, Methyl Red and Voges Proskauer (MRVP), Citrate and Triple Sugar Iron tests were performed following standard protocol ${ }^{10}$.

Standardized agar disc-diffusion method was used to determine the antibiotic susceptibility patterns of bacteria isolated from juice samples ${ }^{13}$. Pure and fresh culture of Klebsiella spp. Vibrio spp. $(\mathrm{n}=2)$, Staphylococcus spp. Enterobacter sp. Proteus sp. were suspended in $1 \mathrm{ml}$ of sterile normal saline. Turbidity of the suspension was compared with $0.5 \mathrm{McF}$ arland standards. After appropriate turbidity was attained, these suspensions were inoculated and spread over the Muller Hinton agar plates using cotton swabs. Erythromycin $(15 \mu \mathrm{g})$, Amoxicillin $(10 \mu \mathrm{g})$, Gentamicin $(10 \mu \mathrm{g})$, Vancomycin $(30 \mu \mathrm{g})$, Ciprofloxacin $(5 \mu \mathrm{g})$, Rifampicin $(5 \mu \mathrm{g})$, Azithromycin $(15 \mu \mathrm{g})$, Neomycin $(10 \mu \mathrm{g})$, Cefexime $(5 \mu \mathrm{g})$ were placed onto the plate and incubated at $37^{\circ} \mathrm{C}$ for 24 hours. The diameters of zone of inhibition for individual antibiotics were interpreted as susceptible, intermediate and resistant categories according to the Clinical Laboratory Standards Institue ${ }^{14}$.

Table 1 shows the presence of microbial load of ten different fruit juice samples. In our study all samples were found to be contaminated with either one or more pathogenic bacteria.

In Bangladesh, fruit juices are becoming more and more popular as they are usually more delicious than other soft drinks. Due to their taste, low price, and availability at right time, street vended fruit juices, are well appreciated by consumers ${ }^{15,16}$. However, these juices can serve as media for microbial growth and can cause outbreaks of diseases. Most of the juice related outbreak occurs by the Salmonella spp., such as, S. typhymurium, S. enteric, S. muenchen etc. In 1980 a severe outbreak took place due to enterotoxigenic Escherichia coli ${ }^{1,17}$.

In present study, 10 fruit juice samples were chosen randomly from different locations in Dhaka city. Eight samples showed the presence of one or more pathogenic microorganisms. Presence of pathogenic bacteria in juice samples is harmful for human health if they are consumed without further processing. The highest contamination was recorded in sugarcane juice which is

Table 1. Total Microbial Count

\begin{tabular}{|c|c|c|c|c|c|c|c|c|}
\hline Sample & TVB & $\begin{array}{c}\text { Total } \\
\text { coliform }\end{array}$ & $\begin{array}{l}\text { Staphylococcus } \\
\text { spp. }\end{array}$ & $\begin{array}{l}\text { Vibrio } \\
\text { spp. }\end{array}$ & $\begin{array}{l}\text { Salmonella } \\
\text { spp. }\end{array}$ & $\begin{array}{c}\text { Shigella } \\
\text { spp. }\end{array}$ & $\begin{array}{l}\text { Pseudomonas } \\
\text { spp. }\end{array}$ & $\begin{array}{c}\text { Fungal } \\
\text { spp. }\end{array}$ \\
\hline Papaya juice-1 & $11.2 \times 10^{6}$ & 0 & $2 \times 10^{5}$ & + & 0 & 0 & $6.8 \times 10^{5}$ & $1.16 \times 10^{6}$ \\
\hline Papaya juice-2 & $1.52 \times 10^{7}$ & $1.2 \times 10^{5}$ & $5.2 \times 10^{5}$ & + & 0 & 0 & $1.52 \times 10^{6}$ & $5.12 \times 10^{6}$ \\
\hline Wood apple juice-1 & $5.68 \times 10^{7}$ & $4 \times 10^{4}$ & 0 & + & 0 & 0 & $4.4 \times 10^{6}$ & $2.52 \times 10^{6}$ \\
\hline Wood apple juice-2 & $1.44 \times 10^{7}$ & $4 \times 10^{4}$ & $4 \times 10^{4}$ & + & 0 & 0 & $5.2 \times 10^{5}$ & $2.2 \times 10^{6}$ \\
\hline Lemon juice-1 & 0 & 0 & 0 & - & 0 & 0 & 0 & 0 \\
\hline Sugarcane juice-1 & $5.24 \times 10^{7}$ & $4.4 \times 10^{5}$ & $4 \times 10^{5}$ & + & 0 & 0 & $4.72 \times 10^{6}$ & $4.8 \times 10^{6}$ \\
\hline Sugarcane juice-2 & $8.12 \times 10^{6}$ & $3.2 \times 10^{5}$ & $3 \times 10^{4}$ & + & 0 & 0 & $4.8 \times 10^{6}$ & $6 \times 10^{6}$ \\
\hline Sugarcane juice- 3 & $8 \times 10^{6}$ & $2 \times 10^{5}$ & 0 & + & 0 & 0 & $6 \times 10^{6}$ & $6.8 \times 10^{6}$ \\
\hline
\end{tabular}

$\mathrm{TVB}=$ Total Viable Bacterial count

Colonies form different selective media were subculture on different media and were subjected to different biochemical tests as mentioned in following table. 
Table 2. Biochemical results

\begin{tabular}{|c|c|c|c|c|c|c|c|c|c|c|c|c|}
\hline \multirow[b]{2}{*}{ 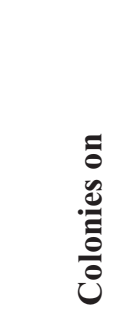 } & \multirow[b]{2}{*}{ 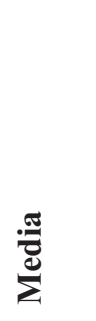 } & \multirow[b]{2}{*}{ 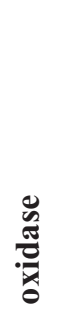 } & \multirow[b]{2}{*}{ 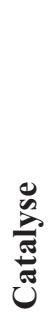 } & \multirow[b]{2}{*}{ 鴶 } & \multicolumn{4}{|c|}{ IMViC } & \multicolumn{3}{|c|}{ KIA } & \multirow[b]{2}{*}{ Suspected organism } \\
\hline & & & & & $\frac{0}{\frac{0}{0}}$ & $\underline{z}$ & 5 & $\underset{0}{\stackrel{0}{*}}$ & 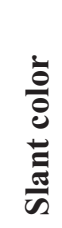 & 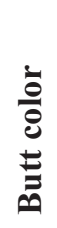 & 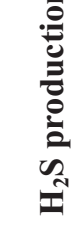 & \\
\hline \multicolumn{2}{|c|}{ MFC (blue) } & - & - & + & - & - & - & + & $\mathrm{Y}$ & $\mathrm{Y}$ & + & Klebsiella spp. \\
\hline \multicolumn{2}{|c|}{ TCBS (yellow) } & - & - & + & - & - & - & + & $\mathrm{Y}$ & $\mathrm{Y}$ & - & Vibrio spp. \\
\hline \multicolumn{2}{|c|}{ MSA (yellow) } & - & + & + & - & + & - & - & $\mathrm{Y}$ & $\mathrm{Y}$ & - & Staphylococcus spp. \\
\hline \multicolumn{2}{|c|}{ MFC (blue) } & - & - & + & - & - & - & + & $\mathrm{Y}$ & $\mathrm{Y}$ & + & Enterobacter spp. \\
\hline \multicolumn{2}{|c|}{ TCBS (green) } & - & - & + & - & - & - & - & $\mathrm{Y}$ & $\mathrm{R}$ & - & Vibrio spp. \\
\hline \multicolumn{2}{|c|}{ TCBS (green) } & - & - & + & - & + & - & - & $\mathrm{Y}$ & $\mathrm{Y}$ & - & Vibrio spp. \\
\hline \multicolumn{2}{|l|}{ PA } & - & - & + & + & + & - & - & $\mathrm{R}$ & $\mathrm{Y}$ & - & Proteus spp. \\
\hline
\end{tabular}

possibly linked to the poor microbiological quality of raw materials used in the preparation of juices ${ }^{7,17,18}$. Only lemon juice samples showed no growth of microorganisms. It may be due to low $\mathrm{pH}$ of lemon juice, which caused reduction in microbial growth $^{16}$.

Most of the fruit juice samples showed much higher count of TVC than recommended value.

The highest bacterial load was found in a wood apple juice $\left(5.68 \times 10^{7} \mathrm{cfu} / \mathrm{ml}\right)$, collected from Baily road and the lowest bacterial load $\left(1.6 \times 10^{6} \mathrm{cfu} / \mathrm{ml}\right)$ was found in a wood apple and papaya mix juice, which was collected from New market. Variations in TVC of both types of fruit juices may be due to the unhygienic maintenance during preparing the juice ${ }^{7,17,18}$. In a previous study in Nagpur, India, total bacterial counts in juice samples were found to range between $2.0 \times 10^{6}$ and $1.0 \times 10^{5} \mathrm{cfu} /$ $\mathrm{ml}^{19}$. Another study in Dhaka, microorganisms in freshly squeezed fruit juice were found to range from $3 \times 10^{2}$ to $9.6 \times 10^{8} \mathrm{cfu} / \mathrm{ml}^{19}$. In the present study, microbial load in juice samples ranged between $8.0 \times 10^{6}$ and $5.68 \times 10^{7} \mathrm{cfu} / \mathrm{ml}$ which is similar to the findings of other researchers ${ }^{18,19}$. However, TVC $>10^{4} \mathrm{cfu} / \mathrm{ml}$ is responsible for the spoilage of fruit juices ${ }^{20-22}$. Thus tested samples are not safe for consumption.

The limit of staphylococci in fruit juice sample is $10^{3} \mathrm{cfu} / \mathrm{ml}^{20-}$ 22 . Coagulase-positive staphylococci may cause human disease through production of toxins ${ }^{23}$, if present in $10^{5}-10^{6} \mathrm{cfu} / \mathrm{ml}$ of food $^{24}$. In the present study, staphylococci were found in 6 out of 10 samples tested. The highest count of total staphylococci $\left(5.2 \times 10^{5} \mathrm{cfu} / \mathrm{ml}\right)$ was found in papaya juice, collected from Gulisthan. Several other reports have shown the prevalence of staphylococci in fruit juice samples ${ }^{25,27}$. As the tested samples have outnumbered the standard staphylococcal limit for safe food consumption, they are potential source of food borne disease outbreaks.

In the present study coliforms were found in 6 out of 10 samples which ranged between $4.0 \times 10^{4}$ and $4.4 \times 10^{5} \mathrm{cfu} / \mathrm{ml}$. As the presence of coliforms is high in number $\left(>2.0 \log _{10} \mathrm{cfu} / \mathrm{ml}\right)$ and beyond acceptable limit and can cause spoilage of fruit juices and food borne diseases ${ }^{21-23}$. High concentrations of coliforms in these 6 samples render them unsuitable for drinking. The highest coliform count was found in sugarcane juice $\left(4.4 \times 10^{5}\right.$ $\mathrm{cfu} / \mathrm{ml}$ ) which was collected from Gulisthan area. In another study on different types of vended squeezed fruit juices in Dhaka city in Bangladesh showed the presence of $E$. coli ranging from 43 to $>2.4 \times 10^{3} \mathrm{cfu} / 100 \mathrm{ml}^{19}$. High level of contamination of fruit juices by $E$. coli were reported in a different study in India as well ${ }^{18}$. These organisms are indicator organism and may cause serious disease in humans. Citrobacter spp. causes urinary infections, infections in gall bladder, middle ear etc. Enterobacter spp. are responsible for urinary tract infections and hospital sepsis etc. Different pathotypes of Escherichia coli cause diarrhea, urinary infections and septicemia etc. ${ }^{20,27,28}$ Some strains like E. coli O157 produce the enterotoxin shiga toxin which cause hemolytic uremic syndrome 29,30 .

Vibrio spp. are able to form viable but nonculturable (VBNC) state and needs enrichment for isolation. Upon enrichment 8 out 
of 10 fruit juices showed the presence of Vibrio spp. Several species of Vibrio are pathogenic and a significant number of fruit and vegetable borne outbreaks were reported in previous studies. ${ }^{12,20}$ Most disease causing strains are associated with gastroenteritis, but can also infect open wounds and cause septicemia. Vibrio cholerae infects the intestine and increases fluid and electrolyte secretion causing diarrhea and vomiting which result in extreme dehydration and death if not treated properly $^{31,20}$.

Salmonella is another important pathogen and generally only a problem in fresh, unpasteurised fruit juices, due to its low thermal tolerance. Three major outbreaks of Salmonellosis, all from unpasteurised orange juice, have been documented in the United States, Canada and Australia, involving 62, 298 and 400 reported cases in 1995 and $1999^{32}$. But in the current research Salmonella and Shigella were not found in any of the sample tested.

Mean values of fungal species found in fruit juice samples are presented in Table 1. Aspergillusis the major toxogenic fungi ${ }^{33}$ that produce aflatoxins are mycotoxins which are produce as teratogenic, carcinogenic and mutagenic secondary metabolites ${ }^{3}$. The highest fungal growth $\left(5.12 \times 10^{6} \mathrm{cfu} / \mathrm{ml}\right)$ was found in one of the papaya juices collected from Gulisthan area.

Nine broad-spectrum antibiotics were used to form the antibiotic resistance pattern which illustrated in Table 3. Drug resistance is becoming more and more threat for the global public health. The antibiogram result showed that most of the isolates are resistant to more than one antibiotic.

In the present study, most of the organism showed multi drug resistant property. Klebsiella spp. was found to be resistant against 4 out of 8 antibiotics including, Erythomycin $(15 \mu \mathrm{g})$, Amoxicillin $(10 \mu \mathrm{g})$, Vancomycin $(30 \mu \mathrm{g})$ and Rifampicin $(5 \mu \mathrm{g})$. Enterobacter aerogenes and Proteus vulgaris showed similar resistance pattern. Both the isolates were found resistant against 4 antibioticsErythomycin $(15 \mu \mathrm{g})$, Amoxicillin $(10 \mu \mathrm{g})$, Rifampicin $(5 \mu \mathrm{g})$ and Cefixime $(5 \mu \mathrm{g})$. Vibrio parahaemolyticus showed resistance against all nine antibiotics. Vibrio cholera was resistant against Amoxicillin, $10 \mu \mathrm{g}$; Rifampicin, $5 \mu \mathrm{g}$ Azithromycin $15 \mu \mathrm{g}$ and Cefixime $5 \mu \mathrm{g}$ and was intermediately resistant against Erythomycin $15 \mu \mathrm{g}$ and Neomycin $10 \mu \mathrm{g}$. and Staphylococcus aureus was the only organism which was sensitive to each tested antibiotic. Prevalence of drug resistance property in these isolates can cause serious health hazards and question effective treatment of the sufferers by commonly prescribed antibiotics ${ }^{35}$.

Taste, low price and availability make street vended juices highly popular to general people. But these drinks will be beneficial if these are of good quality and microbiologically safe for consumption. Over all the results of the study indicate that all street vended fresh juices in many parts of the Dhaka City are contaminated with high load of TVC, total coliform, Staphylococci, fungi and Vibrio spp. It is contended that contamination is mainly due to poor quality of water used for dilution as well as prevailing poor hygienic conditions maintained by the vendors and vending area. The location by the side of a busy road with heavy vehicular traffic (airborne particles) or by the side of the waste disposal system and overcrowding seem to add to the contamination. Such area should be avoided for establishing a street vender juice shop. Prevalence of pathogenic faecal coliforms, Staphylococci and Vibrio spp. is alarming enough for an immediate action by the suitable agency. Strict and regular monitoring of the quality of fruit juices for human consumption must be introduced to avoid any future pathogen outbreaks. Guideline should be made to restrict the use of antibiotic and emergence of drug resistant organism from these food items.

Table 3. Antibiogram of isolated bacteria

\begin{tabular}{lcccccc}
\hline Bacteria/Name of antibiotic & Klebsiella spp. & Vibrio spp. & Staphylococcus spp. & Enterobacter $\mathrm{sp}$. & Vibrio spp. & Proteus spp. \\
\hline Erythromycin $(\mathbf{1 5} \mu \mathrm{g})$ & $\mathrm{R}$ & $\mathrm{I}$ & $\mathrm{S}$ & $\mathrm{R}$ & $\mathrm{R}$ & $\mathrm{R}$ \\
Amoxicillin $(10 \mu \mathrm{g})$ & $\mathrm{R}$ & $\mathrm{R}$ & $\mathrm{S}$ & $\mathrm{R}$ & $\mathrm{R}$ & $\mathrm{R}$ \\
Gentamicin $(10 \mu \mathrm{g})$ & $\mathrm{S}$ & $\mathrm{S}$ & $\mathrm{S}$ & $\mathrm{S}$ & $\mathrm{R}$ & $\mathrm{S}$ \\
Vancomycin $(30 \mu \mathrm{g})$ & $\mathrm{R}$ & $\mathrm{S}$ & $\mathrm{S}$ & $\mathrm{R}$ & $\mathrm{R}$ & $\mathrm{R}$ \\
Ciprofloxacin $(5 \mu \mathrm{g})$ & $\mathrm{S}$ & $\mathrm{S}$ & $\mathrm{S}$ & $\mathrm{S}$ & $\mathrm{R}$ & $\mathrm{S}$ \\
Rifampicin & $\mathrm{R}$ & $\mathrm{R}$ & $\mathrm{S}$ & $\mathrm{R}$ & $\mathrm{R}$ & $\mathrm{R}$ \\
Azithromycin $(15 \mu \mathrm{g})$ & $\mathrm{S}$ & $\mathrm{R}$ & $\mathrm{S}$ & $\mathrm{S}$ & $\mathrm{R}$ & $\mathrm{S}$ \\
Neomycin $(10 \mu \mathrm{g})$ & $\mathrm{I}$ & $\mathrm{I}$ & $\mathrm{S}$ & $\mathrm{I}$ & $\mathrm{R}$ & $\mathrm{I}$ \\
Cefexime $(5 \mu \mathrm{g})$ & $\mathrm{S}$ & $\mathrm{R}$ & $\mathrm{R}$ & $\mathrm{R}$ & $\mathrm{R}$ & $\mathrm{S}$ \\
\hline
\end{tabular}

Measurements were in millimeter $(\mathrm{mm})$; $\mathrm{R}=$ Resistant, $\mathrm{I}=$ Intermediate, $\mathrm{S}=$ Sensitive 


\section{Reference}

1. Babiye B. 2017. Isolation and Identification of Bacteria from fresh fruit Juice Prepared in Cafeterias and Restaurants, Axum Town, Ethiopia. Biosci Biotech Res Asia. 14(1): 307-313.

2. Dewanti-Hariyadi R, 2013. Microbiological Quality and Safety of Fruit Juices. FOOD REVIEW International. 1(1): 54-57.

3. Sospedra I, Rubert J, Soriano JM, and Mãnes J. 2012. Incidence of microorganisms from fresh orange juice processed by squeezing machines. Food Control, 23(1): 282-285

4. Kaur A, Sood A, Kaur S and Bhowate P. 2017. Bacterial Population Associated with Fruits and Vegetables and its Treatment using Antimicrobial Rinsing. Int. J. Curr. Microbiol. App. Sci. 6(12): 20992107

5. Lewis JE, Thompson P, Rao BVVBN, Kalavati C and Rajanna B. 2006. Human bacteria in street vended fruit juices: A case study of Visakhapatnam city, India. Internet J. Food Safe. 8: 35-38.

6. Qadri OA, Yousuf B and Srivastava AK. 2015. Fresh-cut fruits and vegetables: Critical factors influencing microbiology and novel approaches to prevent microbial risks-A review. Cogent Food Agriculture, 1: 1121606

7. Sharma PU. 2013. Bacteriological analysis of street vended fruit juices available in Vidarbha. Int. J. Curr. Microbiol. Appl. Sci. 2(5): 178-183

8. Chikwendu CI, Nwabueze RN and Anyanwu BN. 2008. Antibiotic resistance profile of Escherichia coli from clinically healthy pigs and their commercial farm environments. African Journal of Microbiology Research, 2: 012-017.

9. American Public Health Association. 1998. Standard Methods for the Examination of Water and Wastewater, 20 ${ }^{\text {th }}$ Ed. American Public Health Association, Washington, D.C.

10. Cappuccino G and Sherman N. 2014. Microbiology: Laboratory manuals, 10th ed., Benjamin/Cummings, San Francisco, USA.

11. Piangka N, Ahmed T and Acharjee M. 2016. Microbiological analysis for drug resistant pathogenic microorganisms with determination of the antibacterial properties found in Fragaria xananassa (strawberry) samples. Stam. J. Microbiol, 6(1): 16-19

12. Shammi T. 2015. Detection of Vibrio spp., Salmonella spp., and Shigella spp. among the frozen food samples employing enrichment culture technique. Stam. J. Microbiol. 5(1):26-9.

13. Bauer AW, Kirby WMM, Sherris JC and Tierch M. 1968. Antibiotic Susceptibility Testing by a Standardized Single Disc Method. Am. J. Clin. Pathol. 45(4): 493-496.

14. Clinical and Laboratory Standard Institute (CLSI). 2006. Performance standards for antimicrobial susceptibility testing. USA: CLSI: M100-S16. Wayne, PA.

15. FAO. 2007. The informal food sector. http://www. informalfood.unibo.it 2007-11-23.

16. Ohiokpehai O. 2003. Nutritional Aspects of street foods in Botswana. Pakistan J. Nutr. 2(2): 76-81.

17. Prescott LM, Harley JP and Klein, DA. 2002. Microbiology: Food and Industrial Microbiology. 5th Edition, McGraw-Hill, Boston.

18. Bagde NI and Tumane PM. 2011. Studies on microbial flora of fruit juice and cold drinks. Asiatic J. Biotech. Res. 2(4): 454-460.
19. Ahmed MSU, Nasreen T, Feroz B and Parveen S. 2009. Microbiological Quality of Local Market Vended Freshly Squeezed Fruit Juices in Dhaka City, Bangladesh. Bangladesh J. Sci. Ind. Res. 44(4); 421-424.

20. Khan MM, Islam MT, Chowdhury MMS and Alim SR. 2015. Int. J. Food Cont. 2(4):1-5.

21. Gulf Standards, 2000. Microbiological criteria for foodstuffs-part 1.GCC, Riyadh, Saudi Arabia.

22. Codex Alimentarius Commission. 2005. Codex general standard for fruit juices and nectars. Codex Standard 2005; 247: 1-19. www.codexalimentarius.net

23. Iqbal MN, Anjum AA, Ali MA, Hussain F, Ali S, Muhammad A, Irfan M, Ahmad A, Irfan M and Shabbir A. 2015. Assessment of Microbial Load of Un-pasteurized Fruit Juices and in vitro Antibacterial Potential of Honey Against Bacterial Isolates. The Open Microbiol. J. 9: 26-32.

24. Guidi F, Duranti A, Gallina Y, Petruzzelli A, Romano A, Travaglini V, Olivastri A, Calvaresi V, Decastelli L and Blasi G. 2018. Characterization of A Staphylococcal Food Poisoning Outbreak in A Workplace Canteen during the Post-Earthquake Reconstruction of Central Italy. Toxins. 10(12): 523 .

25. IDF. 1994. Recommendations for the hygienic manufacture of milk and milk based products, appendix A. In Spoilage and pathogenic bacteria in milk based products, p. 28-30. International Dairy Federation, Belgium.

26. Tambekar DH, Jaiswal VJ, Dhanorkar DV, Gulhane, PB and Dudhane MN. 2009. Microbial Quality and safety of street vended fruit juices: A case study of Amravati city. Int. J. Food Safety. 10: 72-76.

27. Ananthanarayan R and JayaramPaniker CK. 1996. Text Book of Microbiology, $5^{\text {th }}$ edn. Orient Longman Limited, Chennai, 40-43, 250-261

28. Falagas ME, Rafailidis PI, Kofteridis D, Virtzili S, Chelvatzoglou FC and Papaioannou V. 1988. Packaging for Fruits, Vegetables and Root Crops. FAO. Rome. 21.

29. Koster $F$ et al. 1978. Hemolytic uremic syndrome after shigellosis: relation toendotoxemia and circulating immune complexes. $N$ Engl J Med. 298: 927-933.

30. Croxen MA, Law RJ, Scholz R, Keeney KM, Wlodarska M and Finlay BB. 2013. Recent advances in understanding enteric pathogenic Escherichia coli. Clinic. Microbiol. Rev. 26(4): 822-80.

31. Howard-Jones N, 1984. Robert Koch and the cholera vibrio: a centenary. BMJ. 288(6414): 379-381.

32. Wareing P and Davenport RR. 2007. Microbiology of Soft Drinks and Fruit Juices. Chemistry and Technology of Soft Drinks and Fruit Juices, Second Edition, 279-299.

33. D'Mello JPF and Macdonald AMC. 1997. Mycotoxins. Anim. Feed Sci. Tech. 69: 155-166.

34. Frisvad JC, Skouboe P and Samson RA. 2005. Taxonomic comparison of three different groups of aflatoxin producers and a new efficient producer of aflatoxin B1, sterigmatocystin and 3-Omethylsterigmatocystin, Aspergillu srambellii. System. Appl. Microbiol. 28: 442-453.

35. Ventola CL. 2015. The Antibiotic Resistance Crisis: Part 1: Causes and Threats. Pharmacy \& Theraputics, 40(4): 277-283. 